\title{
Self-Emulsifying Formulation of Indomethacin with Improved Dissolution and Oral Absorption
}

\author{
İndomethacinin Geliştirilmiş Çözünürlük ve Sözlü İzolasyon ile \\ Formülasyonunun Özel Emülsifilleştirilmesi
}

\author{
Subhash Chandra Bose PENJURI*, Saritha DAMINENI², Nagaraju RAVOURU³, Srikanth Reddy POREDDY \\ 'Mnr College of Pharmacy, Department of Pharmaceutics, Telangana, India \\ 2Sultan-ul-uloom College of Pharmacy, Department of Pharmaceutics, Telangana, India \\ ${ }^{3}$ Sri Padmavathi Mahila Visvavidyalayam (Women's University), Institute of Pharmaceutical Technology, Andhra Pradesh, India
}

\begin{abstract}
Objectives: The objective of the present study was to enhance the solubility, dissolution and hence anti-inflammatory activity of poorly soluble drug indomethacin (IMN) by formulating into self emulsifying systems.

Materials and Methods: Self emulsifying formulations were prepared using capmul MCM as oil, tween 80 as surfactant, transcutol P as cosurfactant. Fourier transform infrared spectroscopy and differential scanning calorimetry studies were conducted to know the interaction between drug and excipients. Pseudo ternary phase diagrams were constructed using surfactant and cosurfactant in 1:1 to 1:4 and 2:1 to 4:1 to know the efficient self emulsification region. The formulations were evaluated for their particle size, zeta potential, refractive index, viscosity and cloud point. In vitro dissolution studies were conducted in one part of pH 7.2 phosphate buffer and four parts of water. The pharmacokinetic parameters were analysed by Win Nonlin software.

Results: The self emulsification was higher with the ratios 2:1, 3:1 and 1:2 of surfactant and co surfactant and the IMN formulations were prepared. The formulations were stable at different $\mathrm{pH}$ and dilutions. The globule size was in the range of $184.1 \mathrm{~nm}$ to $340.5 \mathrm{~nm}$, as the ratio of oil, surfactant and cosurfactant mixture has varied effects on the size of globule. The negative charge on the globules of all formulations attributes their stability. The optimized formulation showed better release as compared to marketed product. The AUC of the optimised Self-Emulsifying Drug Delivery System was significantly higher than the marketed product.

Conclusion: Thus, from the present research, self emulsifying systems of IMN provide a useful alternative to enhance dissolution and hence anti inflammatory activity.
\end{abstract}

Key words: Self emulsifying drug delivery system, pseudo ternary phase diagram, zeta potential, anti-inflammatory activity, indomethacin, AUC

öz

Amaç: Bu çalışmanın amacı, kendiliğinden emülsifiye edici sistemlere formüle ederek, az çözünen ilaç indometazinin (IMN) çözünürlüğünü, çözünmesini ve dolayısıyla anti-inflamatuvar aktiviteyi artırmaktır.

Gereç ve Yöntemler: Kendi kendine emülsiyon haline getirici formülasyonlar yağ olarak capmul MCM, yüzey aktif madde olarak tween 80 , kosürfaktant olarak transcutol P kullanılarak hazırlandı. İlaç ve eksipiyanlar arasındaki etkileşimi bilmek için fourier dönüşüm kızılötesi spektroskopisi ve diferansiyel tarama kalorimetrisi çalışmaları yapılmıştır. Pseudo üçlü faz diyagramları, kendinden emülsiyonlaşmış bölgeyi bilmek için 1:1 ile 1:4 ve 2:1 ile 4:1 arasında yüzey aktif madde ve kosürfaktant kullanılarak oluşturulmuştur. Formülasyonlar, parçacık büyüklüğü, zeta potansiyeli, kırılma indisi, viskozite ve bulut noktası açısından değerlendirildi. In vitro çözünme çalışmaları, pH 7.2 fosfat tamponun bir bölümünde ve dört kısım suda gerçekleștirildi. Farmakokinetik parametreler Win Nonlin yazıımı ile analiz edildi.

Bulgular: Kendiliğinden emülsifikasyon 2:1, 3:1 ve 1:2 oranında surfaktan ve kosürfaktant oranlarına göre daha yüksekti ve IMN formülasyonları hazırlandı. Formülasyonlar, farklı pH ve seyreltmelerde kararlıydı. Küre boyutu, $184.1 \mathrm{~nm}$ ile $340.5 \mathrm{~nm}$ aralığındaydı, çünkü yağ, yüzey aktif madde ve ko-yüzey aktif madde karışımı oranı kürenin boyutuna farklı etkiler yapmıștır. Tüm formülasyonların globüllerinin üzerindeki negatif yük, kararlılıklarına atıfta bulunmaktadır. Optimize edilmiş formülasyon, pazarlanan ürüne kıyasla daha iyi salınım gösterdi. Optimize edilmiş Kendi Kendine Emülsifiye Edici İlaç Taşıma Sistemi'nin AUC'si pazarlanan ürüne göre önemli derecede yüksekti.

Sonuç: Böylece, mevcut araştırmadan kendi kendine emülsifiye IMN sistemleri, çözünmeyi ve dolayısıyla anti-inflamatuvar aktiviteyi arttırmak için yararlı bir alternatif sağlar.

Anahtar kelimeler: Öz hazırlama için ilaç dağıtım sistemi, sözde üçlü faz diyagramı, zeta potansiyel, anti-inflamatuvar faaliyet, indometazin, AUC

*Correspondence: E-mail: penjurisubhash@gmail.com, Phone: +919848033974

ORCID ID: orcid.org/0000-0002-9365-0701

Received: 06.10.2016, Accepted: 21.11.2016

๑Turk J Pharm Sci, Published by Galenos Publishing House. 


\section{INTRODUCTION}

About $90 \%$ of all compounds in today's pharmaceutical drug delivery pipelines are reported to be poorly soluble in water.' This poses enormous problems for the industry; for an active pharmaceutical ingredient that cannot reach its molecular target in the body if drug remains undissolved in the gastrointestinal tract (GIT) and is eventually excreted. The ability to increase aqueous solubility is thus a valuable aid to increase the efficacy of certain drugs. ${ }^{2}$ So, solubilisation techniques that overcome this issue by increasing the solubility of drugs are becoming more and more important to pharmaceutical industry. ${ }^{3}$ Currently a number of technologies are available to deal with the poor solubility, dissolution rate and bioavailability of insoluble drugs. One of the most popular approaches of oral bioavailability and solubility enhancement is the utilization of lipid-based drug delivery systems (LBDDS). 4,5 Self-Emulsifying Drug Delivery System (SEDDS) are proportionate newer LBDDS with huge promise in oral bioavailability enhancement of drugs. These formulations avoid the slow and incomplete dissolution of a drug, increase the extent of its transportation and bypass the P-gp efflux, thereby strengthen drug absorption from the GIT. ${ }^{6}$

The major technique for enhancing bio-availability is SEDDS, which uses lipophilic, pre-concentrated solutions of the active pharmaceutical ingredient and excipients (a liquid carrier, a surfactant and a cosurfactant). They emulsify spontaneously when, come in contact with fluids of GIT to form oil-in-water emulsions or microemulsions under mild agitation.? In the design and development of SEDDS, modified long and medium chain triglyceride oils, with different degrees of saturation or hydrolysis are widely used because they offer definite physiological and formulation related advantages, as their degradation products simulate that of the natural end products of intestinal digestion. ${ }^{8-10}$

Surfactants, being amphiphilic in nature, can solubilize high amounts of lipophilic drugs. Usually surfactants will be selected based on hydrophilic-lipophilic balance (HLB) values and safety." The most widely recommended emulsifiers include the non-ionic surfactants with relatively high HLB values. Nonionic surfactants are considered as safer than the ionic ones.12-15 Self-emulsification occurs when the entropy change that favors dispersion is greater than the energy required to increase the surface area of the dispersion. ${ }^{16}$ Protection of drugs in the gut, reduction in gastric irritation, consistent drug absorption and enhanced oral bioavailability are advantages of SEDDS.17-21 So the aim of present work was to develop self emulsifying formulations of indomethacin (IMN) to enhance its solubility and hence bioavailability.

\section{MATERIALS AND METHODS}

\section{Materials}

IMN was a gift obtained from Micro Labs Limited, Bangalore. Mefenamic acid was obtained from Dr. Reddy's Laboratories Ltd. (Hyderabad). Acetonitrile was purchased from Qualigens fine Chemicals (Mumbai). Castor oil, Propylene glycol and PEG 400 was purchased from Merck (Mumbai). Labrafil M 2125, labrasol, Plurol oleique CC 497, Transcutol P and Labrafac WL 1349 were obtained from Gattefosse India Pvt Ltd. (Mumbai). Oleic acid was purchased from Merck (Mumbai). Soya bean oil and sunflower oil were purchased from Genuine chemicals Co. (Mumbai). Isopropyl myristate was purchased from Lobachemie Pvt Ltd (Mumbai). Cremophor RH 40 was obtained from BASF (Mumbai). Tween 80 was purchased from Finar Chemicals (Ahmadabad). Water (HPLC grade) was purchased from Qualigens fine Chemicals (Mumbai).

\section{Bioanalytical method}

A HPLC method was used to quantify the amount of IMN in the rat plasma samples obtained during the pharmacokinetic study. The analysis was performed using Intelligent LC 3000 system, sodium acetate buffer $\mathrm{pH} 3.6$ and acetonitrile (40:60) was used as mobile phase with a flow rate of $1 \mathrm{~mL} / \mathrm{min}$ ODS (C-18), BP 5 $\mu \mathrm{m}, 250 \times 4.6 \mathrm{~mm}$ was the column used at ambient temperature. The detector wave length and injection volume were $320 \mathrm{~nm}$ and $20 \mathrm{~mL}$ respectively. Linearity $\left(r^{2}=0.998\right)$ was obtained in the concentration range $0.2-5 \mu \mathrm{g} / \mathrm{mL} .^{22,23}$

\section{Solubility study of IMN in various oils and surfactants}

A calibration curve was plotted for IMN in a mixture of ethanol:water (1:1) in the range of 10-50 $\mu \mathrm{g} / \mathrm{mL}$ (Beer's Lambert's range) at $320 \mathrm{~nm}$. A good linear relationship was observed between the concentration of IMN and its absorbance in a mixture of ethanol:water $\left(r^{2}=0.9986, m=0.0186, n=3\right)$. Excess amount of IMN was placed in glass vials and mixed manually in $2 \mathrm{~mL}$ of various oils/surfactants/cosurfactants. The vials were sonicated for $2 \mathrm{~h}$ and centrifuged at $3000 \mathrm{rpm}$ for $20 \mathrm{~min}$, followed by filtration. The filtrate was diluted with mixture of ethanol:water (1:1) and the amount of IMN dissolved in various vehicles was analysed by ultraviolet (UV) spectrophotometric method (Shimadzu, Japan). ${ }^{24-26}$

\section{Determination of emulsification efficiency}

Equal amount of surfactant and oil was mixed and gradually heated at $50^{\circ} \mathrm{C}$ for uniform homogenization. $100 \mathrm{mg}$ of mixture was diluted with $100 \mathrm{~mL}$ of water in a stoppered conical flask. Emulsification efficiency was determined by number of inversions required to yield homogenous emulsion. Emulsion was allowed to stand for $2 \mathrm{~h}$ and its percentage transmittance was determined at $638 \mathrm{~nm}$ by UV-Visible spectrophotometer (Shimadzu, Japan) using distilled water as blank. ${ }^{27}$

\section{Fourier transform infrared spectroscopy}

Compatibility studies between IMN, oil and Smix was studied by fourier transform infrared spectroscopy (FTIR) (Perkin Elmer Model 1600, USA). Pure drug and physical mixture were dissolved in dichloromethane separately. By using a capillary tube, a smear/thin film of the samples was placed on the $\mathrm{NaCl}$ crystal cell (hexagonal clear, about $2 \mathrm{~mm}$ thickness). It was sandwiched with another $\mathrm{NaCl}$ crystal cell. The $\mathrm{NaCl}$ cells with the sandwiched sample were placed in sample holder. The samples were scanned from 4000 to $400 / \mathrm{cm}$ using FTIR spectrophotometer. 


\section{Differential scanning calorimetry}

Compatibility studies between IMN, oil and Smix was studied by Differential scanning calorimetry [differential scanning calorimetry (DSC)-60, Shimadzu Corporation, Japan]. Liquid samples are placed in dome shaped sample holder and sealed. Then the sample is placed in the right side pocket, with empty cell on left side as blank. Dry nitrogen was used as effluent gas. All samples were scanned at a temperature ramp speed of $5^{\circ} \mathrm{C} /$ min and the heat flow from $0^{\circ} \mathrm{C}$ to $200^{\circ} \mathrm{C}$.

\section{Construction of pseudoternary phase diagram}

Pseudoternary phase diagrams were developed by titrating capmul MCM, tween 80 and transcutol $P$ mixture with water. The trails were conducted using oil and Smix in the ratios 1:1 to 1:9. The surfactant and co surfactant ratios 1:1, 1:2, 1:3, 1:4, 4:1, 3:1, 2:1 were tested in the construction of pseudoternary phase diagrams. After each addition of water the dispersion was observed physically for clarity. Phase diagrams were constructed using Tri-Plot V1-4-2.28 The ratios with good emulsification were further tested.

\section{Thermodynamic stability studies}

Thermodynamic stability studies of formulations were carried by exposing them to heating cooling cycle, centrifugation test and freeze thaw test. ${ }^{29}$

\section{Heating cooling cycle}

Formulations were kept at $4^{\circ} \mathrm{C}$ and then at $40^{\circ} \mathrm{C}$ in a cyclic way about six times. The formulations were exposed to each temperature for $48 \mathrm{~h}$. Formulations were observed physically for turbidity at the end of test period.

\section{Centrifugation test}

Formulations were centrifuged at $3500 \mathrm{rpm}$ for $30 \mathrm{~min}$ and observed for any phase separation.

\section{Freeze thaw test}

Formulations were kept at $-21^{\circ} \mathrm{C}$ and then at $25^{\circ} \mathrm{C}$ in a cyclic way about three times. Formulations were observed physically for turbidity at the end of test period. Stable formulations were considered for further evaluation.

\section{Determination of dispersion ability}

$1 \mathrm{~mL}$ of each formulation was added in $500 \mathrm{~mL}$ of water at $37 \pm 1^{\circ} \mathrm{C}$. A standard stainless steel dissolution paddle is used with rotating speed of $50 \mathrm{rpm}$ which provided gentle agitation. The in vitro performance of the formulations is visually assessed using the grading system as given in Table $1{ }^{30}$

\section{Drug precipitation study}

IMN SEDDS were taken into $250 \mathrm{~mL}$ water and mixed under continuous stirring $(100 \mathrm{rpm})$ on magnetic stirrer. The formed emulsion was then observed visually after a period of $24 \mathrm{~h}$ for the precipitation of drug. The self-emulsifying systems were then considered as stable (without precipitation) or unstable (with precipitation). ${ }^{31}$

\section{Preparation of SEDDS}

Based on the solubility, emulsification ability and pseudo-ternary phase diagram studies excipients were selected. Formulation was limited to only the SEDDS that passed the thermodynamic stability studies, dispersion ability and precipitation study. Accurately weighed amount of IMN was dissolved initially in capmul MCM (oil). Tween 80 and transcutol P (surfactant and cosurfactant) mixture were accurately weighed and added slowly to the drug-oil mixture. The mixture was heated at $40^{\circ} \mathrm{C}$ on a magnetic stirrer, until IMN was perfectly dissolved. Then the mixture was sealed in a glass capped vial and stored at room temperature until used.

\section{Evaluation of SEDDS}

Drug content

A calibration curve was plotted for IMN in a mixture of ethanol: water (1:1) in the range of 10-50 $\mu \mathrm{g} / \mathrm{mL}$ (Beer's Lambert's range) at $320 \mathrm{~nm}$. A good linear relationship was observed between the concentration of IMN and its absorbance in a mixture of ethanol:water $\left(r^{2}=0.9986, m=0.0186, n=3\right)$. Drug from preweighed SEDDS is extracted by dissolving in ethanol:water (1:1) for IMN respectively and the drug content was analyzed by UV spectrophotometer (Shimadzu, Japan). ${ }^{23}$

\section{Refractive index and percent transmittance}

$1 \mathrm{~mL}$ of formulation diluted to $100 \mathrm{~mL}$ with water and a drop of it was placed on the Abbe's refractometer prism, RI value was determined in the presence of a visible light source (Tungsten lamp). The percent transmittance of formulations was measured at $650 \mathrm{~nm}$ using UV spectrophotometer (Shimadzu, Japan). Distilled water was used as a blank. ${ }^{32}$

\section{Viscosity}

$0.5 \mathrm{gm}$ of SEDDS was diluted to 10 times with distilled water and viscosity of the resultant emulsion was measured using Brookfield viscometer with spindle \# CPE40.31

\section{Effect of $\mathrm{pH}$ and robustness to dilution}

SEDDS were subjected to 100 fold dilution with distilled water, $0.1 \mathrm{~N} \mathrm{HCl}$ and phosphate buffer $\mathrm{pH}$ 6.8. The resultant diluted emulsions were checked for coalescence of globules and phase separation after $24 \mathrm{~h}$ storage. ${ }^{33}$

\begin{tabular}{lll} 
Table 1. Visual assessment of efficiency of self emulsification \\
Grade & Dispersibility \& appearance & $\begin{array}{l}\text { Time of self } \\
\text { emulsification }\end{array}$ \\
\hline 1 & $\begin{array}{l}\text { Rapid forming microemulsion which is } \\
\text { clear or slightly bluish in appearance }\end{array}$ & $<1 \mathrm{~min}$ \\
\hline 2 & $\begin{array}{l}\text { Rapid forming, slightly less clear emul- } \\
\text { sion which has bluish white appearance }\end{array}$ & $<2 \mathrm{~min}$ \\
\hline 3 & $\begin{array}{l}\text { Bright white emulsion (similar to milk in } \\
\text { appearance) }\end{array}$ & $<3$ min \\
\hline 4 & $\begin{array}{l}\text { Dull, greyish whitish emulsion with a } \\
\text { slightly oily appearance that is slow to } \\
\text { emulsify }\end{array}$ & $>3$ min \\
\hline 5 & $\begin{array}{l}\text { Exhibit poor or minimal emulsification } \\
\text { with large oil globules present on the } \\
\text { surface }\end{array}$ & $>3$ min \\
\hline
\end{tabular}




\section{Size analysis and homogeneity of SEDDS}

The mean globule size, zeta potential and polydispersity index of SEDDS were measured by photon correlation spectroscopy instrument (Zetasizer 3000HS, Malvern Instruments Corp., U.K.) at $25^{\circ} \mathrm{C} .{ }^{34}$ For measurement, SEDDS was pre-diluted by addition of $0.6 \mathrm{~mL}$ of SEDDS to $90 \mathrm{~mL}$ of distilled water under slow agitation at room temperature $\left(25^{\circ} \mathrm{C}\right)$. The system was analyzed by dispersing it in $100 \mathrm{~mL}$ distilled water as dispersant. Analysis was done in triplicate and mean results are presented. The sizing and zeta potential of the SEDDS was determined in a small volume module. Samples were directly placed into the module and the data was collected for $10 \mathrm{~min}$. All studies were repeated in triplicates, with good agreement being found between the measurements.

\section{Turbidimetric evaluation}

Equal quantity of SEDDS and $0.1 \mathrm{~N} \mathrm{HCl}$ was mixed under continuous stirring ( $50 \mathrm{rpm}$ ) on magnetic hot plate at $37 \pm 0.5^{\circ} \mathrm{C}$ temperature. The turbidity was measured by using a turbidimeter (Digital nephelo-turbidity meter 132, Systronics, India). ${ }^{35,36}$

\section{Cloud point measurement}

The cloud point value of optimized formulations were determined and compared. Each formulation was diluted with water in the ratio of 1:100 and placed in a water bath with gradual increase $\left(2^{\circ} \mathrm{C} / \mathrm{min}\right.$ ) in temperature (from 25 to $80^{\circ} \mathrm{C}$ ). Cloud point was measured as the temperature at which there was a sudden appearance of cloudiness as seen visually. ${ }^{27}$

\section{In vitro release study}

A calibration curve was plotted for IMN in one part of $7.2 \mathrm{pH}$ phosphate buffer and four parts of water in the range of 10 $50 \mu \mathrm{g} / \mathrm{mL}$ (Beer's Lambert's range) at $320 \mathrm{~nm}$. A good linear relationship was observed between the concentration of IMN and its absorbance in one part of $7.2 \mathrm{pH}$ phosphate buffer and four parts of water $\left(r^{2}=0.9997, m=0.0189, n=3\right)$. In vitro release of optimized formulations capsules filled with (SEDDS), marketed product and pure drug each containing $25 \mathrm{mg}$ of IMN were carried using USP type 1 dissolution apparatus (Model No TDT-08L, Electrolab, Mumbai). One part of pH 7.2 Phosphate buffer and four parts of water was used as dissolution medium maintained at $37 \pm 0.5^{\circ} \mathrm{C}$ with the basket rotating at $100 \mathrm{rpm}$. Samples $(10 \mathrm{~mL})$ were withdrawn at regular intervals and the same volume of fresh dissolution medium was replaced to maintain sink condition. ${ }^{25}$ The samples were filtered, diluted and analyzed UV spectrophotometrically at $320 \mathrm{~nm}$ (Shimadzu, Japan). Dissolution studies were performed and the mean cumulative percentage of IMN was calculated and plotted against time. In vitro dissolution data was statistically analysed by one way ANOVA followed by turkey post hoc test for multiple comparison using graph pad prism. Differences were considered to be significant at a level of $p<0.05$. Dissolution profile of optimized formulations and marketed product was compared on the basis of their similarity factor ( $f 2$ ) and difference factor ( $f 1$ ).

\section{In vitro diffusion study}

A calibration curve was plotted for IMN in in one part of $7.2 \mathrm{pH}$ phosphate buffer and four parts of water in the range of 10 -
$50 \mu \mathrm{g} / \mathrm{mL}$ (Beer's Lambert's range) at $320 \mathrm{~nm}$. A good linear relationship was observed between the concentration of IMN and its absorbance in one part of $7.2 \mathrm{pH}$ phosphate buffer and four parts of water $\left(r^{2}=0.9997, m=0.0189, n=3\right)$. In vitro diffusion studies of optimized SEDDS and marketed products were carried by dialysis method. $250 \mathrm{~mL}$ of one part of $\mathrm{pH} 7.2$ phosphate buffer and four parts of water was used as diffusion medium for IMN-B1. Temperature was maintained at $37^{\circ} \mathrm{C}$ with the paddle speed of $100 \mathrm{rpm}$. Samples were withdrawn at regular intervals of time for $12 \mathrm{~h}$ and drug concentration was analyzed by UV spectrophotometer (Shimadzu, Japan). The data was statistically analysed by $t$ test $(p<0.05)$ using graph pad prism. ${ }^{31}$

\section{Pharmacodynamic studies}

\section{Anti-inflammatory studies}

The anti-inflammatory activity of optimized and marketed formulations of IMN was evaluated by the carrageenan-induced rat hind paw edema method by using Digital plethysmometer (PLM-01 plus, Orchid Scientifics, India). Study protocol was approved by IAEC (Reg. No. IAEC/SUCP/CPCSEA/08/2013). The animals were divided into three groups (six animals in each group) for anti-inflammatory studies. ${ }^{37,38}$ Wistar strain male albino rats weighing between (150-200 g) were used. The animals were in a light controlled 12 hours cycle with free access to food and water. Animals were fasted overnight before experiment with free access to water. Animals were divided into three groups of six animals each. Group 1 (control) received water. Group 2 received $10 \mathrm{mg} / \mathrm{kg}$ formulated SEDDS and group 3 received $10 \mathrm{mg} / \mathrm{kg}$ marketed product. After one hour, paw edema was induced by injecting $50 \mu \mathrm{L}$ of $1 \% \mathrm{w} / \mathrm{v}$ carrageenan into the sub planar region of the left hind paw. Paw volume was determined after $5 \mathrm{~h}$ in all groups. Difference in the paw volume, determined before and after injection of the edema-provoking agent indicated the severity of edema. One control group and reference group were used in this study. Volumes of right hind paw of controls and treated animals were measured with a plethysmometer and the percentage inhibition of inflammatory reaction was determined for each animal by comparison with control and calculated by the following formula.

$\%$ inhibition of edema $=\frac{\left(V_{\text {control }}-V_{\text {test }}\right)}{V_{\text {control }}} \times 100$

Where,

$\mathrm{V}_{\text {control }}=$ mean edema of rats in control group

$\mathrm{V}_{\text {test }}=$ mean edema volume of rats in tested group

\section{Pharmacokinetic evaluation}

Pharmacokinetic study protocol was approved by the IAEC (Reg. No. IAEC/MNRCOP/CPCSEA/09-04-2013). The oral pharmacokinetics of IMN was assessed in wistar rats. Animals were fasted overnight with free access to water for at least $12 \mathrm{~h}$ before dosing. After collecting the zero hour blood sample (blank), the formulations were given orally $(10 \mathrm{mg} / \mathrm{kg}$ body weight). The animals were then anesthetized and blood 
samples were withdrawn from the tail vein and placed in heparinised centrifuge tubes. The plasma was then separated and assayed for the concentration of IMN by HPLC. Table 2 shows the specifications of animals used for in vivo study. The pharmacokinetic parameters were calculated using WinNonlin software. ${ }^{39,40}$ The animals were divided into three groups;

Group 1: IMN suspension [pure IMN in 1\% carboxymethylcellulose $(\mathrm{CMC})]$ administered animals.

Group 2:

IMN-B1 administered animals.

Group 3:

Marketed product (in 1\% CMC) administered animals.

\section{Stability study}

Stability studies were conducted according to the ICH Q1A (R2) guidelines. Formulations were packed in a screw capped bottle and were kept in stability chamber at a temperature of $40 \pm 2^{\circ} \mathrm{C}$ and $75 \pm 5 \% \mathrm{RH}$ for 6 months. Samples were withdrawn at the end of 1, 2, 3 and 6 months and analyzed for drug content, homogeneity, clarity, globule size and release. Zero time samples were used as control for the study. ${ }^{41,42}$

\section{RESULTS AND DISCUSSION}

\section{Selection of oil, surfactant and cosurfactant}

Solubility of indomethacin in oils, surfactants and co surfactants The selection of oil, surfactant and cosurfactant for the formulation of SEDDS was initially based on the solubility of IMN in these excipients. IMN solubility in various oils and surfactants is shown in Table 3. Capmul MCM showed maximum solubility of IMN so it was selected as oil; labrasol and tween 80 which showed good solubility were selected as surfactants for further study. The solubility of IMN in surfactant and oil is important, as cosurfactants on dilution with water may separate out resulting in micellar dispersion, thus reducing the solvent capacity for IMN. ${ }^{43}$ So, all the cosurfactants were further used in the study.

\section{Emulsification ability}

The oil, surfactant and cosurfactants which showed good solubility were tested for their emulsification ability. Capmul MCM showed good solubility of IMN which helps to prevent precipitation in the intestinal fluids ${ }^{44}$, so the emulsification

\section{Table 2. Animal specifications for in vivo study}

\begin{tabular}{ll} 
Species & Wistar rats \\
\hline Weight & $150-200 \mathrm{gm}$ \\
\hline Gender & Male/Female \\
\hline No. of animals in each group & 6 \\
\hline Total time of the study & $24 \mathrm{~h}$ \\
\hline No. of blood samples from each animal & 12 \\
\hline Sampling intervals (h) & $0.5,1,1.5,2,3,4,5,6,8$, \\
\hline Volume of the blood sample & $12,16,24$ \\
\hline
\end{tabular}

efficiency of this oil is studied with surfactants labrasol, tween 80 and cosurfactants transcutol P, plurol oleique CC, PG and PEG 400 which showed good solubility of IMN. The emulsification efficiency results as indicated by inversions and percentage transmittance are given in Table 4. Better emulsification efficiency is given by lesser number of inversions. ${ }^{8}$ The number of inversions required for tween 80 , labrasol, transcutol $P, P E G$ 400, PG and plurol oleique CC was found to be $9,15,6,8,11$ and 17 respectively.

Percentage transmittance of labrasol and tween 80 was 94.8 and 99.1 respectively. As the emulsification efficiency and solubility of IMN was greater with tween 80 , it was selected as surfactant in the further study. The percentage transmittance of cosurfactants transcutol P, PEG 400, PG and plurol oleique CC was found to be 96.5, 93.7, 88.3 and 82 respectively. Based on the solubility and emulsification of IMN with oil, transcutol P was selected as cosurfactant.

\section{Compatibility studies}

The FTIR spectra of IMN and physical mixture are shown in Figure 1. The characteristic peaks of IMN are unchanged and

\begin{tabular}{llll}
\multicolumn{4}{l}{ Table 3. Solubility of IMN in various oils/surfactants } \\
Oil/surfactant & $\begin{array}{l}\text { Solubility } \\
(\mathrm{mg} / \mathrm{mL})\end{array}$ & Oil/surfactant & $\begin{array}{l}\text { Solubility } \\
(\mathrm{mg} / \mathrm{mL})\end{array}$ \\
\hline Castor oil & $11.48 \pm 1.26$ & Tween 80 & $119.34 \pm 1.20$ \\
\hline Oleic acid & $6.79 \pm 2.71$ & Cremophor RH 40 & $90.72 \pm 1.82$ \\
\hline Labrafil M2125 & $15.16 \pm 0.93$ & Labrasol & $167.38 \pm 0.87$ \\
\hline Sunflower oil & $10.32 \pm 1.59$ & Transcutol P & $192.1 \pm 1.39$ \\
\hline Soya bean oil & $18.48 \pm 1.15$ & Plurol oleique CC & $150.17 \pm 2.01$ \\
\hline Labrafac lipophile & $29.23 \pm 0.96$ & PG & $121.21 \pm 1.99$ \\
WL 1349 & $35.14 \pm 1.84$ & PEG 400 & $98.57 \pm 0.58$ \\
\hline IPM & $51.87 \pm 2.11$ & & \\
\hline Capmul MCM & & &
\end{tabular}

Mean \pm standard deviation, $n=3, I M N$ : Indomethacin

Table 4. Emulsification efficiency of surfactants and cosurfactants with capmul MCM

\begin{tabular}{lll} 
Surfactant/cosurfactant & $\begin{array}{l}\text { Number of } \\
\text { inversions }\end{array}$ & $\begin{array}{l}\text { Percentage } \\
\text { transmittance }\end{array}$ \\
\hline Tween 80 & $9 \pm 2$ & 99.1 \\
\hline Labrasol & $15 \pm 2$ & 94.8 \\
\hline Transcutol P & $6 \pm 3$ & 96.5 \\
\hline Plurol oleique CC & $17 \pm 3$ & 82.0 \\
\hline PG & $11 \pm 2$ & 88.3 \\
\hline PEG 400 & $8 \pm 2$ & 93.7 \\
\hline
\end{tabular}

Mean \pm standard deviation, $\mathrm{n}=3$ 
prominently observed in FTIR spectra of physical mixture suggesting that there was no interaction between IMN and excipients. DSC thermograms of pure IMN and physical mixture are presented in Figure 2. The DSC thermograms showed sharp melting peak for IMN, at $161^{\circ} \mathrm{C}$. A small endothermic peak with low intensity was observed at $161^{\circ} \mathrm{C}$ in physical mixture, may be due to reduction in drug crystallinity and molecular dispersion of IMN in the lipid excipients.

\section{Construction of pseudoternary phase diagram}

Pseudoternary diagrams form the basis for selection of composition of components for SEDDS. They were constructed with capmul MCM as oil, mixture of tween 80 and transcutol $P$ as

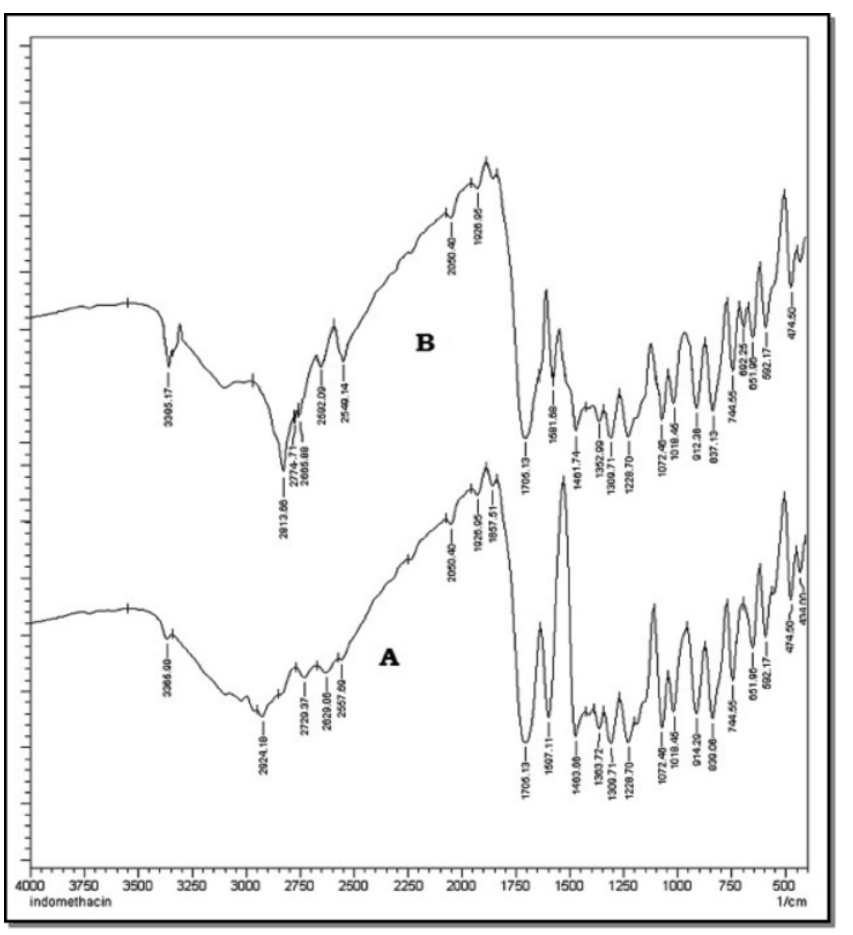

Figure 1. FTIR spectra of $A$ : indomethacin and $B$ : physical mixture FTIR: Fourier transform infrared spectroscopy

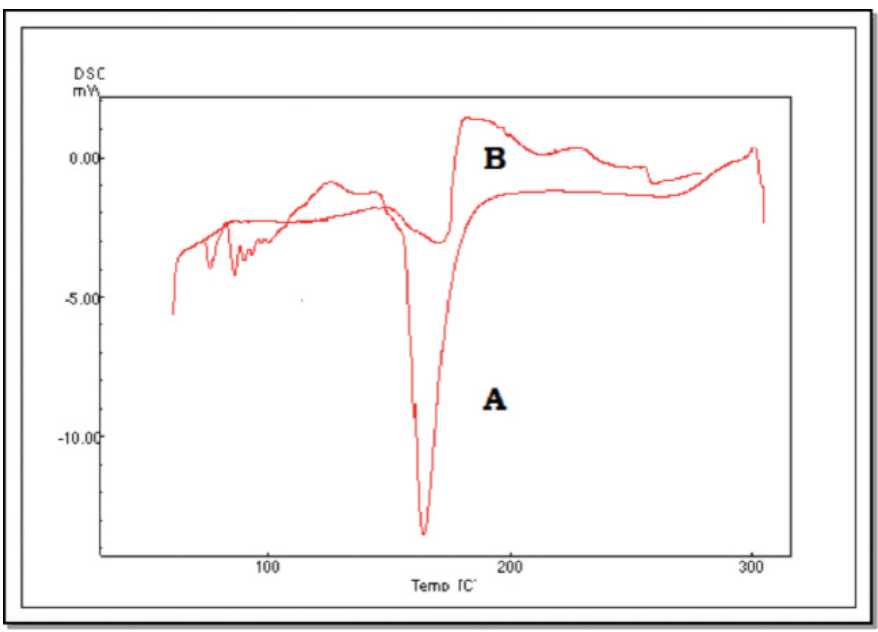

Figure 2. Differential scanning calorimetry thermograms of A: indomethacin and B: physical mixture surfactant mixture with IMN and water (Figure 3). The process of self micro emulsification was observed to be spontaneous as the energy required to form is less. The selected surfactant mixture is a combination of low and high HLB value, which makes it a more efficient SEDDS. 43,45

The microemulsion region was observed in pseudo ternary diagrams. The phase diagrams which showed maximum self emulsification region were with tween 80 and transcutol $P$ in the ratios 2:1, 3:1 and 1:2. Increase in tween 80 concentration (2:1 to 3:1) showed spontaneous and better emulsification which may be due to formation of monolayers of surfactant on the emulsion globules which increases the stability. A slight increase in cosurfactant ratio (1:2) showed good emulsification region as, transcutol $P$ may have fluidized the surfactant making it flexible to form microemulsion. So the S:Co ratios of 2:1, 3:1 and 1:2 which showed maximum self micro emulsification region were used and various formulations were made for further study shown in Table 5.

\section{Dispersion ability}

An efficient SEDDS formulation disperses very fast in seconds provided the condition of gentle stirring. ${ }^{8}$ The dispersion rate
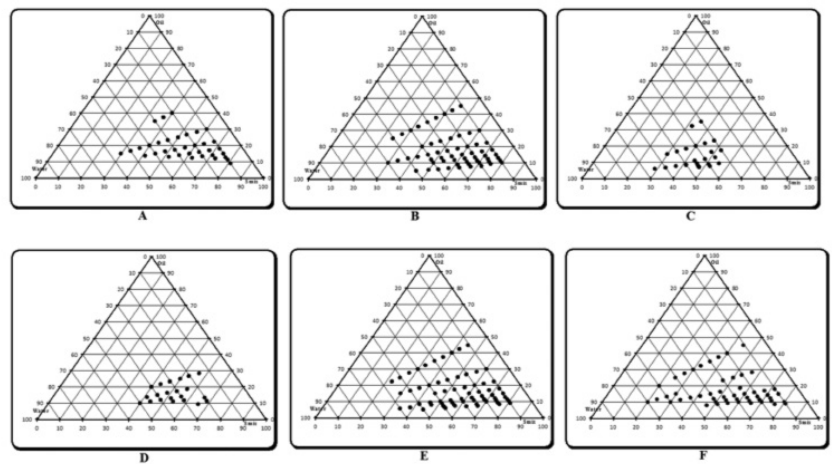

Figure 3. Pseudoternary phase diagram showing the $o / w$ emulsion region of capmul, tween 80 and transcutol $P$ at Smix ratio of $A$ is 1:1, B is 1:2, C is $1: 3, D$ is $1: 4, E$ is $2: 1, F$ is $3: 1$

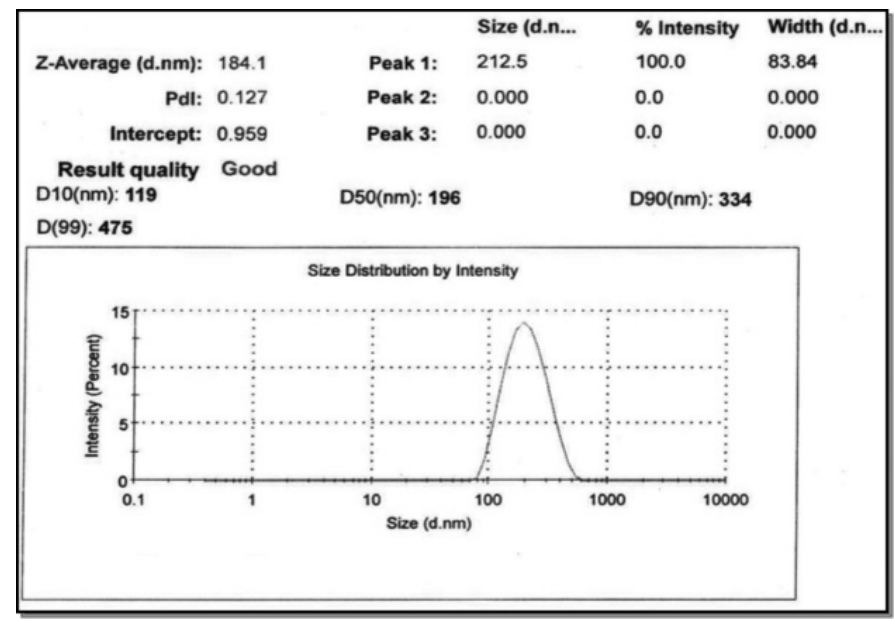

Figure 4. Globule size data of IMN-B1 IMN: Indomethacin 
depends on the interfacial barrier at the oil and dilution medium interface. Tween 80 and transcutol $P$ at the ratios 2:1, 3:1 and 1:2 showed good dispersion as shown in Table 6 may be due to formation of stable interfacial film. Formulations which showed dispersibility grade of 1 and 2 were selected for further study.

\section{Thermodynamic stability and precipitation study}

The stability of the formulations affects the performance and instability may result in precipitation or phase separation. The effect of metastable forms, which are difficult to find, can be eliminated by the thermodynamic studies. The formulations were subjected to centrifugation, heating, cooling cycles, freeze thaw test. Results were shown in Table 6. The concentration of surfactant and cosurfactant has varied effects and is important for a stable microemulsion formation. Formulations which have passed the thermodynamic stability study, dispersion test and drug precipitation study were optimised and further evaluated. IMN-A1, IMN-A2, IMN-A3, IMN-B1, IMN-B2 and IMN-C2 were selected as optimized formulations as they passed the stability study.

\section{Evaluation of optimized IMN SEDDS formulations}

\section{Drug content}

The IMN content in the formulations is given in Table 7 which showed uniform distribution. All the formulations have drug content in the range $99.1 \pm 1.92$ to $100.3 \pm 0.91 \%$.

\section{Percentage transmission and refractive index}

Refractive index of the formulations was in the range of 1.434-1.447, nearly same as that of water as shown in Table 7. The percentage transmission was found to be in the range 95.4 to 99.2 . The results indicated that the optimized SEDDS formulations are translucent and clear dispersions.

\section{Viscosity}

The viscosity of optimised formulations is shown in Table 7. Viscosity of the system plays an important role in drug release. It was reported that low viscosity of the systems will result in $\mathrm{o} / \mathrm{w}$ emulsions. The viscosity of the formulations was in the range of $0.656 \mathrm{cps}$ to $0.932 \mathrm{cps}$.

\section{Dilution and $\mathrm{pH}$ effect}

All the formulations were stable when diluted to 100 times with water, $0.1 \mathrm{~N} \mathrm{HCl}$ and $\mathrm{pH} 6.8$ phosphate buffer. There was no phase separation or precipitation which indicates the non ionic surfactants used were stable to change in $\mathrm{pH}$ and the concentration of electrolyte. ${ }^{46}$ This is necessary for stable emulsion system as it gets in contact with various physiological fluids in the system.

\section{Table 5. Composition of SEDDS formulations}

\begin{tabular}{|c|c|c|c|c|c|c|}
\hline S: Co S & $2: 1$ & & & & & \\
\hline O: Smix & $1: 1$ & $1: 2$ & $1: 3$ & $1: 4$ & $1: 5$ & $1: 6$ \\
\hline Tween 80 & 325 & 433.4 & 487.6 & 520 & 541.7 & 557.2 \\
\hline Transcutol P & 162.5 & 216.6 & 243.7 & 260 & 270.8 & 278.6 \\
\hline Capmul MCM & 487.5 & 325 & 243.7 & 195 & 162.5 & 139.3 \\
\hline Formulation code & $\mid \mathrm{MN}-\mathrm{A} 1$ & IMN-A2 & IMN-A3 & IMN-A4 & IMN-A5 & IMN-A6 \\
\hline S: Co S & $3: 1$ & & & & & \\
\hline O: Smix & $1: 1$ & $1: 2$ & $1: 3$ & $1: 4$ & $1: 5$ & 1:6 \\
\hline Tween 80 & 365.6 & 487.5 & 548.4 & 585 & 609.3 & 626.7 \\
\hline Formulation code & IMN-B1 & IMN-B2 & IMN-B3 & IMN-B4 & IMN-B5 & IMN-B6 \\
\hline S: Co S & $1: 2$ & & & & & \\
\hline O: Smix & $1: 1$ & $1: 2$ & $1: 3$ & $1: 4$ & $1: 5$ & $1: 6$ \\
\hline Tween 80 & 162.5 & 216.6 & 243.7 & 260 & 270.8 & 278.6 \\
\hline Transcutol P & 325 & 433.4 & 487.6 & 520 & 541.7 & 557.2 \\
\hline Capmul MCM & 487.5 & 325 & 243.7 & 195 & 162.5 & 139.3 \\
\hline Indomethacin & 25 & 25 & 25 & 25 & 25 & 25 \\
\hline
\end{tabular}

IMN: Indomethacin, SEDDS: Self-Emulsifying Drug Delivery System 


\section{Emulsion globule size and zeta potential analysis}

Diffusion of drug can be faster from smaller emulsion globules, which increases dissolution of drug into aqueous medium. The average globule size distribution of the optimised formulations is given in Table 8. The globule size was in the range of 184.1 $\mathrm{nm}$ to $340.5 \mathrm{~nm}$, the ratio of oil, surfactant and cosurfactant mixture has varied effects on the size of globule.

IMN-A1 to IMN-A3, IMN-B1 to IMN-B2 showed an increase in globule size which may be due increase in tween 80 concentration in the formulation, which results in more penetration of water into the emulsion globules resulting in larger size. ${ }^{47}$

IMN-C2 showed a globule size of $237.8 \mathrm{~nm}$, which may be attributed to a higher ratio of transcutol P. Formulation IMN-B1, has shown the smallest size globules (Figure 4). The polydispersibility index of the formulations was less than 1 indicating the uniformity of size distribution within the formulation. ${ }^{48}$

The optimised formulations were checked for their zeta potential and tabulated in Table 8. Zeta potential values were in the range of -7.55 to $-8.48 \mathrm{mV}$. From the results, the negative charge on the globules of all formulations attributes their stability, by causing repulsion between them and thus preventing their coalescence (Figure 5). ${ }^{49}$

\section{Turbidimetric evaluation}

The turbidity which attributes to the clarity and uniformity of emulsification, hence stability of the formulation was measured. A measure of turbidity also gives the knowledge of globule size..$^{50}$ The turbidity values are shown in Table 8 . The lower values indicate that prepared systems were clear and may have

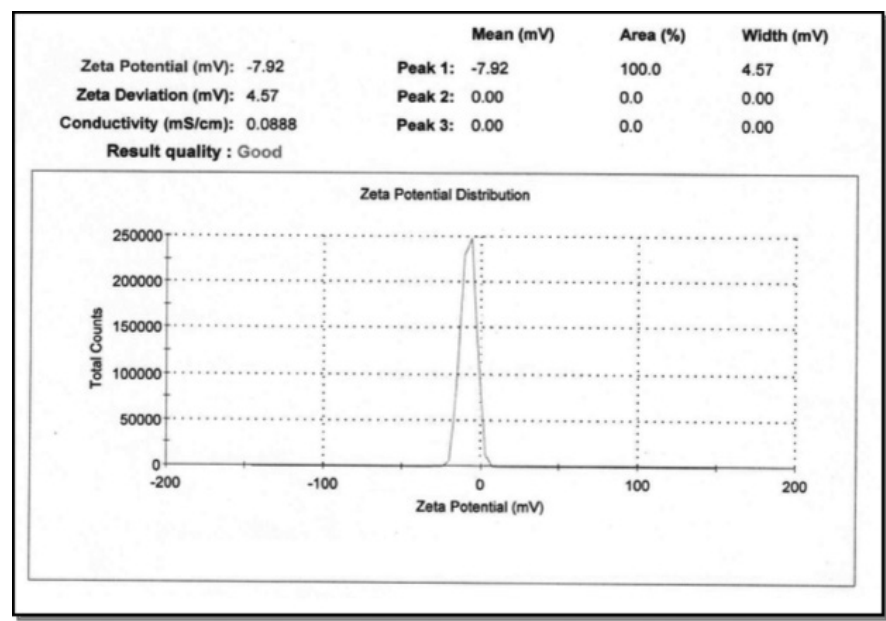

Figure 5. Zeta potential data of IMN-B1

IMN: Indomethacin

Table 6. Results of thermodynamic stability studies, visual dispersion grading

\begin{tabular}{|c|c|c|c|c|c|}
\hline Formulation code & Centrifuge & Heating/Cooling cycle & Freeze thaw & Dispersion grade & Inference \\
\hline IMN-A1 & Pass & Pass & Pass & 2 & Pass \\
\hline IMN-A2 & Pass & Pass & Pass & 2 & Pass \\
\hline IMN-A3 & Pass & Pass & Pass & 2 & Pass \\
\hline IMN-A4 & Pass & Pass & Pass & 2 & Pass \\
\hline IMN-A5 & Pass & Fail & Pass & 3 & Fail \\
\hline IMN-A6 & Pass & Fail & Fail & 3 & Fail \\
\hline IMN-B1 & Pass & Pass & Pass & 2 & Pass \\
\hline IMN-B2 & Pass & Pass & Pass & 2 & Pass \\
\hline IMN-B3 & Pass & Pass & Pass & 2 & Pass \\
\hline IMN-B4 & Pass & Pass & Pass & 2 & Pass \\
\hline IMN-B5 & Pass & Fail & Pass & 2 & Fail \\
\hline IMN-B6 & Fail & Pass & Pass & 3 & Fail \\
\hline IMN-C1 & Pass & Fail & Fail & 2 & Fail \\
\hline IMN-C2 & Pass & Pass & Pass & 2 & Pass \\
\hline IMN-C3 & Pass & Pass & Pass & 2 & Pass \\
\hline IMN-C4 & Pass & Fail & Pass & 2 & Fail \\
\hline IMN-C5 & Fail & Pass & Pass & 3 & Fail \\
\hline IMN-C6 & Pass & Fail & Pass & 3 & Fail \\
\hline
\end{tabular}

Mean \pm standard deviation, $\mathrm{n}=3$, IMN: Indomethacin 
lower globule size. ${ }^{51}$ The decrease in turbidity can be due to the decrease in emulsion globule size.

\section{Cloud point}

The point at which cloudiness appears is known as cloud point. At a temperature higher than the cloud point, formulation may undergo phase separation which is due to dehydration of polyethylene oxide moiety of the non-ionic surfactant. So, cloud point of the formulation should be more than $37^{\circ} \mathrm{C}$. IMN formulations showed cloud point at high temperature $>37^{\circ} \mathrm{C}$ (Table 8), indicating stability at physiological temperature.

\section{In vitro dissolution study}

Faster release of IMN from SEDDS was observed which may be due to dissolved state of IMN, spontaneous formation of microemulsion and smaller globule size, as compared to plain IMN shown in Figure 6.

Formulation IMN-B1 showed the maximum release which may due to its oil and surfactant mixture concentration, which leads to rapid emulsification of oil for finer globules. Nanosized globule provides larger effective surface area for diffusion

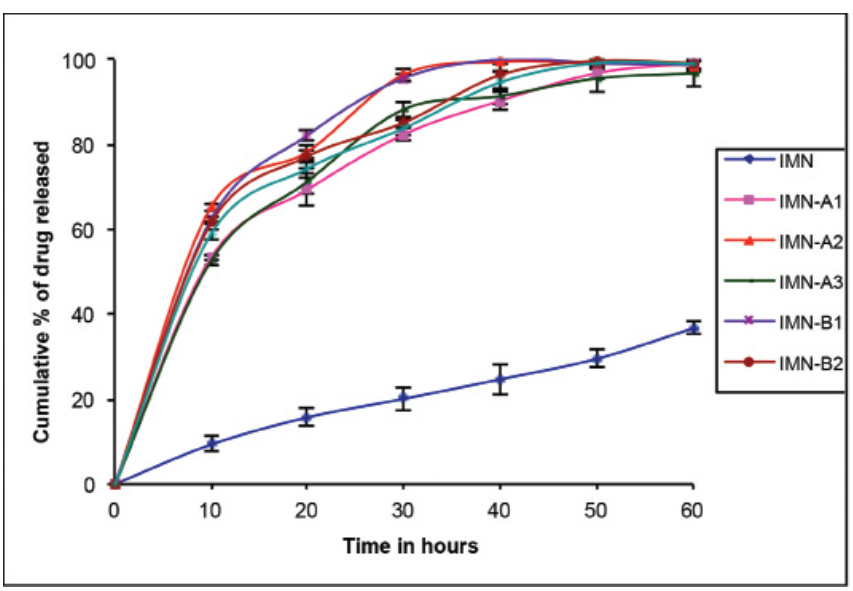

Figure 6. In vitro dissolution profiles of indomethacin formulations of solubilised IMN from SEDDS to dissolution media. ${ }^{44}$ In dissolution study formulation IMN-B1 showed maximum release of drug $(100.12 \pm 1.31 \%)$ in $40 \mathrm{~min}$. The data was analyzed by $t$ test and significant difference ( $p<0.05)$ was observed between means at 10 to $50 \mathrm{~min}$.

In comparison to marketed product dissolution profile of IMN-B1 showed $100.12 \pm 1.31 \%$ of drug release at the end of $40 \mathrm{~min}$, where as marketed product showed $93.68 \pm 2.29 \%$ release at the end of $60 \mathrm{~min}$. The data was analyzed by $t$ test and significant difference was observed between means.

The dissolution profile of the IMN-B1 SEDDS was compared with the marketed product of powder filled capsule by similarity ( $f 2$ ) and dissimilarity factor ( $f 1)$. The low value of $f 2(15 \%)$ and more $\mathrm{f1}(45 \%)$ indicates the dissolution profiles of optimized and marketed product were not similar. The IMN SEDDS has improved dissolution rate of IMN than the powder filled capsule product.

\section{In vitro diffusion study}

In vitro diffusion study for IMN-C1 and marketed product were carried out for $12 \mathrm{~h}$. The percentage release was found to be $81.51 \pm 4.56$ and $57.96 \pm 4.75$ for IMN-C1 and marketed product respectively (Figure 7 ). The data of in vitro diffusion data was analyzed by $t$ test and significant difference was observed between means.

\section{Anti-inflammatory activity}

The percentage inhibition and paw edema in rats showed a significant inhibition ( $p<0.001$ ) compared to control. IMN-B1 showed significant inhibition ( $p<0.05$ and $p<0.01$ ) compared to marketed product due to increased absorption of IMN from lipids. IMN-B1 and marketed product showed the maximum activity at the end of $5^{\text {th }}$ hour of oral administration. Percentage inhibition of IMN-B1 and marketed product was found to be $76.73 \pm 2.84$ and $64.73 \pm 6.83$ respectively. The present study revealed that IMN-B1 showed better anti-inflammatory activity over the marketed product.

\section{Table 7. Drug content, refractive Index, percentage transmission and viscosity of IMN SEDDS}

\begin{tabular}{|c|c|c|c|c|}
\hline Formulation code & Drug content (\%) & Refractive index & Percentage transmission & Viscosity (cps) \\
\hline IMN-A3 & $100.3 \pm 0.91$ & $1.445 \pm 0.02$ & 96.3 & $0.656 \pm 2.11$ \\
\hline IMN-B2 & $99.73 \pm 1.25$ & $1.444 \pm 0.03$ & 96 & $0.872 \pm 1.28$ \\
\hline IMN-C2 & $99.65 \pm 0.94$ & $1.439 \pm 0.03$ & 97.5 & $0.737 \pm 0.94$ \\
\hline
\end{tabular}

Mean \pm standard deviation, $n=3$, SEDDS: Self-Emulsifying Drug Delivery System, IMN: Indomethacin 


\section{Pharmacokinetic studies}

Figure 8 depicts the mean plasma concentration-time profiles of pure IMN, IMN-B1 and marketed product. The plasma level profiles were significantly increased for IMN-B1 and marketed product compared to pure IMN. $\mathrm{C}_{\max }$ was found to be $1.9 \pm 0.22$, $7.87 \pm 0.33$ and $3.58 \pm 0.27 \mu \mathrm{g} / \mathrm{mL}$ for pure IMN, IMN-B1 and marketed product respectively (Table 9 ). $\mathrm{C}_{\max }$ of IMN-B1 and marketed product was 4.14 and 1.88 times higher than that of pure IMN respectively. Time required to reach maximum

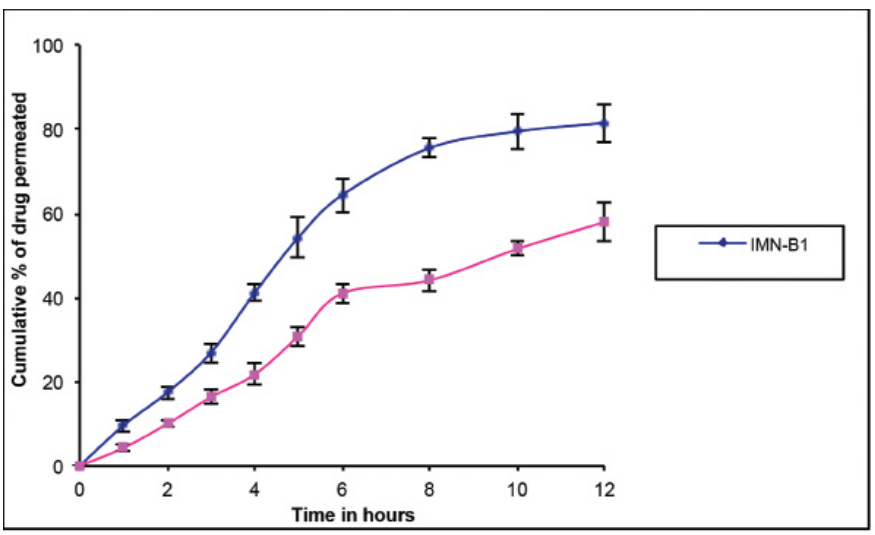

Figure 7. In vitro diffusion profile of IMN-B1 and marketed product IMN: Indomethacin

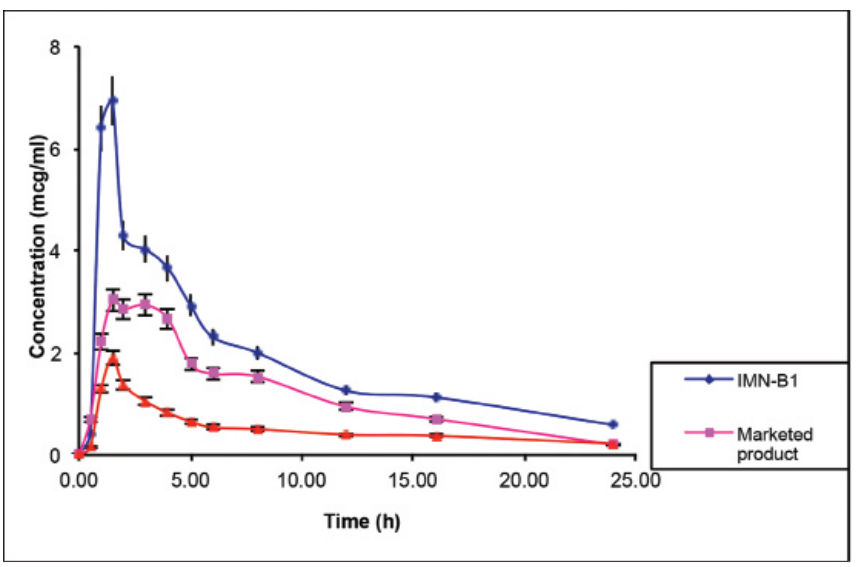

Figure 8. Mean plasma concentration - time profiles of indomethacin concentration was found to be $2.33 \pm 0.58,1.33 \pm 0.29$ and $1.5 \mathrm{hr}$ for pure IMN, IMN-B1 and marketed product respectively.

The low AUC value of pure IMN and marketed product may be due to less absorption into the body. On the contrary, IMN-B1 showed high AUC values indicating increased/better absorption of drug and hence improved bioavailability of IMN from SEDDS. The $t_{1 / 2}$ and $V d$ of IMN was more with the optimized IMN-B1 indicating better drug distribution. The time taken to reach maximum concentration was lesser with IMN-B1 which indicates fast absorption.

\section{Stability study}

No change in the physical parameters such as homogeneity and clarity was observed during the stability study. A slight increase in globule size to $193 \mathrm{~nm}$ has been observed which may be due to aggregation of globules. The PDI was within 1 which reflects the uniformity. The drug content and dissolution behaviour of prepared formulation was well within the limits during the storage and significant difference $(p<0.05)$ was observed between means of drug content at $3^{\text {rd }}$ and $6^{\text {th }}$ month.

\section{CONCLUSION}

In the present study prepared self emulsifying formulations showed enhanced release of IMN when compared to the marketed capsules. SEDDS formed micro emulsion dispersed

\section{Table 9. Pharmacokinetic parameters of IMN in rats after oral dose} of $10 \mathrm{mg} / \mathrm{kg}$

\begin{tabular}{llll}
\multirow{2}{*}{ Parameter } & \multicolumn{2}{l}{ Oral administration } \\
\cline { 2 - 4 } & Pure IMN & IMN-B1 & Marketed product \\
\hline $\mathrm{C}_{\max }(\mathrm{\mu g} / \mathrm{mL})$ & $1.9 \pm 0.22$ & $7.87 \pm 0.33^{\star * *}$ & $3.58 \pm 0.27^{\star * \# \# \#}$ \\
\hline $\mathrm{t}_{\max }(\mathrm{hr})$ & $2.33 \pm 0.58$ & $1.33 \pm 0.29$ & 1.50 \\
\hline $\mathrm{AUC}_{0 \rightarrow \mathrm{t}}(\mathrm{hr} / \mathrm{\mu g} / \mathrm{mL})$ & $12.27 \pm 1.59$ & $43.18 \pm 14.03^{*}$ & $28.09 \pm 3.86$ \\
\hline $\mathrm{AUC}_{0 \rightarrow \infty}(\mathrm{hr} / \mu \mathrm{g} / \mathrm{mL})$ & $16.8 \pm 1.98$ & $60.12 \pm 22.85^{*}$ & $30.03 \pm 5.66$ \\
\hline $\mathrm{t}_{1 / 2}(\mathrm{hr})$ & $7.8 \pm 1.24$ & $7.73 \pm 1.80$ & $5.59 \pm 2.17$ \\
\hline
\end{tabular}

Mean \pm standard deviation, $n=6,{ }^{*} p<0.05,{ }^{* *} p<0.01,{ }^{* *} p<0.001$ vs. pure IMN; ${ }^{*} p<0.5$, $\# \# p<0.001$ vs. IMN-B1, IMN: Indomethacin

\section{Table 8. Globule size, PDI, zeta potential, turbidity and cloud point of IMN SEDDS}

\begin{tabular}{llllll} 
Formulation & Globule size $(\mathrm{nm})$ & PDI & Zeta potential $(\mathrm{mV})$ & Turbidity (NTU) & Cloud point $\left({ }^{\circ} \mathrm{C}\right)$ \\
\hline IMN-A1 & $201.7 \pm 1.83$ & $0.153 \pm 1.32$ & $-7.55 \pm 2.81$ & $10.53 \pm 2.79$ & $74-75$ \\
\hline IMN-A2 & $253.6 \pm 2.55$ & $0.264 \pm 1.71$ & $-7.83 \pm 2.15$ & $19.14 \pm 3.06$ & $71-73$ \\
\hline IMN-A3 & $340.5 \pm 1.74$ & $0.421 \pm 2.11$ & $-7.94 \pm 1.84$ & $20.84 \pm 3.57$ & $63-71$ \\
\hline IMN-B1 & $184.1 \pm 2.07$ & $0.127 \pm 1.67$ & $-7.92 \pm 2.11$ & BLD & $14.27 \pm 3.11$ \\
\hline IMN-B2 & $226.3 \pm 1.79$ & $0.199 \pm 1.83$ & $-8.48 \pm 1.33$ & $17.79 \pm 2.85$ & $62-63$ \\
\hline IMN-C2 & $237.8 \pm 1.19$ & $0.151 \pm 1.06$ & $-8.1 \pm 1.47$ & $62-63$ & 65 \\
\hline
\end{tabular}

Mean \pm standard deviation, $n=3, B L D$ : Below limit of detection, SEDDS: Self-Emulsifying Drug Delivery System, IMN: Indomethacin 
rapidly with a size range $184.1 \mathrm{~nm}$ to $340.5 \mathrm{~nm}$, showing good emulsification. The anti inflammatory activity and pharmacokinetic study showed improved activity as compared to marketed product due to solubilisation of drug by the self emulsification process. Further results show a possible chance of improvement in bioavailability of IMN with the formulated SEDDS. Thus this technique helps in improving solubility and can be applied to similar drugs used in the treatment of various diseases.

\section{ACKNOWLEDGEMENTS}

We thank the Sultan-ul-Uloom educational Society and MNR educational trust, Hyderabad for their valuable support to carry out this research work.

Conflict of Interest: No conflict of interest was declared by the authors.

\section{REFERENCES}

1. Lipinski CA. Poor aqueous solubility: an industry wide problem in drug discovery. Am Pharm Rev. 2002;5:82-88.

2. Yalkowsky S. Technique of solubilization of drugs, drugs and the pharmaceutical sciences. New York; Marcel Dekker; 1981.

3. Amidon GL, Lennernas L, Shah VP, Crison JR. A theoretical basis for a biopharmaceutic drug classification: the correlation of in vitro drug product dissolution and in vivo bioavailability. Pharm Res. 1995;12:413420.

4. Humberstone AJ, Charman WN. Lipid-based vehicles for the oral delivery of poorly water soluble drugs. Adv Drug Deliv Rev. 1997;25:103-128.

5. Gursoy RN, Benita S. Self-emulsifying drug delivery systems (SEDDS) for improved oral delivery of lipophilic drugs. Biomed Pharmacother. 2004;58173-182.

6. Porter $\mathrm{CJ}$, Charman WN. Intestinal lymphatic drug transport: an update. Adv Drug Deliv Rev. 2001;50:61-80.

7. Gao P, Morozowich W. Development of supersaturatable self-emulsifying drug delivery system formulations for improving the oral absorption of poorly soluble drugs. Expert Opin Drug Deliv. 2006;3:97-110.

8. Pouton CW, Porter CJ. Formulation of lipid-based delivery systems for oral administration: materials, methods and strategies. Adv Drug Deliv Rev. 2008;60:625-637.

9. Porter CJ, Trevaskis NL, Charman WN. Lipids and lipid-based formulations: optimizing the oral delivery of lipophilic drugs. Nat Rev Drug Discov. 2007;6:231-248.

10. Chen ML. Lipid excipients and delivery systems for pharmaceutical development: a regulatory perspective. Adv Drug Deliv Rev. 2008;60:768777.

11. Devani M, Ashford M, Craig DQ. The emulsification and solubilisation properties of polyglycolysed oils in self-emulsifying formulations. J Pharm Pharmacol. 2004;56:307-316.

12. Chistyakov BE. Theory and practical application aspects of surfactants. Studies in Interface Science. 2001;13:511-618.

13. Li P, Ghosh A, Wagner RF, Krill S, Joshi YM, Serajuddin AT. Effect of combined use of nonionic surfactant on formation of oil-in-water microemulsions. Int J Pharm. 2005;288:27-34.
14. Lind ML, Jacobsen J, Holm R, Müllertz A. Intestinal lymphatic transport of halofantrine in rats assessed using a chylomicron flow blocking approach: the influence of polysorbate 60 and 80. Eur J Pharm Sci. 2008;35:211-218.

15. Rang MJ, Miller CA. Spontaneous emulsification of oils containing hydrocarbon, nonionic surfactant, and oleyl alcohol. J Colloid Interface Sci. 1999;209:179-192.

16. Reiss H. Entropy induced dispersion of bulk liquids. J Colloid Interface Sci. 1975;53:61-70.

17. Khoo SM, Humberstone AJ, Porter CJH, Edwards GA, Charman WN. Formulation design and bioavailability assessment of lipidic selfemulsifying formulations of halofantrine. Int J Pharm. 1998;167:155-164.

18. Yetukuri K, Sudheer P. Approaches to development of solid self micro emulsifying drug delivery system: formulation techniques and dosage forms: a review. Int J Pharm Sci Res. 2012;3:3550-3558.

19. Sarpal K, Pawar BY, Bansa AK. Self-emulsifying drug delivery systems: a strategy to improve oral bioavailability. Current Research in Pharmaceutical Sciences. 2010;11:42-49.

20. Nidhi M, Shikha S. New strategy for solubilization of poorly soluble drugSEDDS. Der Pharmacia Lettre. 2009;1:60-67.

21. Kawakami K, Yoshikawa T, Hayashi T, Nishihara Y, Masuda K. Microemulsion formulation for enhanced absorption of poorly soluble drugs. II. In vivo study. J Control Release. 2002;81:75-82.

22. Boon V, Glass B, Nimmo A. High-performance liquid chromatographic assay of indomethacin in porcine plasma with applicability to human levels. J Chromatogr Sci. 2006;44:41-44.

23. Li T, Fang L, Ren C, Wang M, Zhao L. Determination of transdermally and orally applied indomethacin in rat plasma and excised skin and muscle samples. AJPS. 2008:3:269-275.

24. Balakrishnan P, Lee BJ, Oh DH, Kim JO, Hong MJ, Jee JP, Kim JA, Yoo BK, Woo JS, Yong CS, Choi HG. Enhanced oral bioavailability of dexibuprofen by a novel solid self emulsifying drug delivery system (SEDDS). Eur J Pharm Biopharm. 2009;72:539-545.

25. Ministry of Health and Family welfare. Indian Pharmacopoeia (6 $6^{\text {th }}$ ed). Ghaziabad: The Indian Pharmacopoeia commission; 2010.

26. Hong JY, Kim JK, Song YK, Park JS, Kim CK. A new self-emulsifying formulation of itraconazole with improved dissolution and oral absorption. J Control Release. 2006;110:332-338.

27. Avachat AM, Patel VG. Self nanoemulsifying drug delivery system of stabilized ellagic acid-phospholipid complex with improved dissolution and permeability. Saudi Pharm J. 2015;23:276-289.

28. Nabi SSU, Shakeel F, Talegaonkar S, Ali J, Baboota S, Ahuja A, Khar RK, Mushir A. Formulation development and optimization using nanoemulsion technique: a technical note. AAPS Pharm Sci Tech. 2007;8:1-6.

29. Shafg S, Shakeel F, Talegaonkar S, Ahmad FJ, Khar RK, Ali M. Development and bioavailability assessment of ramipril nanoemulsion formulation. Eur J Pharm Biopharm. 2007;66:227-243.

30. Khoo SM, Humberstone AJ, Porter CJH, Edwards GA, Charman WN. Formulation design and bioavailability assessment of lipidic selfemulsifying formulations of halofantrine. Int J Pharm. 1998;167:155-164.

31. Patel D, Sawant KK. Oral bioavailability enhancement of acyclovir by self microemulsifying drug delivery systems (SMEDDS). Drug Dev Ind Pharm. 2007;33:1318-1326. 
32. Ramadan E, Borg TH, Abdelghani GM, Saleh N. Formulation and evaluation of acyclovir microemulsions. Bull Pharm Sci. 2013;36:31-47.

33. Kallakunta VR, Bandari S, Jukanti R, Veerareddy PR. Oral self emulsifying powder of lercanidipine hydrochloride: formulation and evaluation. Powder Technol. 2012;221:375-382.

34. Cho HJ, Ku WS, Termsarasab U, Yoon I, Chung CW, Moon HT, Kim DD. Development of udenafil-loaded microemulsions for intranasal delivery: In vitro and in vivo evaluations. Int J Pharm. 2012;423:153-160.

35. Taha El, Al-Saidan S, Samy AM, Khan MA. Preparation and in vitro characterization of self-nanoemulsified drug delivery system (SNEDDS) of all-trans-retinol acetate. Int J Pharm. 2004;285:109-119.

36. Nazzal S, Nutan M, Palamakula A, Shah R, Zaghloul AA, Khan MA Optimization of a self-nanoemulsified tablet dosage form of ubiquinone using response surface methodology: effect of formulation ingredients. Int J Pharm. 2002;240:103-114.

37. Lichtenberger LM, Romero JJ, Dial EJ, Moore JE. Naproxen-PC: a GI safe and highly effective anti-inflammatory. Inflammopharmacology. 2009;17:1-5.

38. Liles JH, Flecknell PA. The use of non-steroidal anti-inflammatory drugs for the relief of pain in laboratory rodents and rabbits. Lab Anim. 1992;26:241-255.

39. Boon V, Glass B, Nimmo A. High-performance liquid chromatographic assay of indomethacin in porcine plasma with applicability to human levels. J Chromatogr Sci. 2006;44:41-44.

40. Saritha D, Penjuri SCB, Nagaraju R. Formulation and evaluation of self emulsifying drug delivery system (SEDDS) of Indomethacin. Int J Res Pharm Sci. 2014;4:17-23.
41. Bachhav YG, Patravale VB. SMEDDS of glyburide: formulation, in vitro evaluation, and stability studies. AAPS Pharm Sci Tech. 2009;10:482-487.

42. Patel AR, Vavia PR. Preparation and in vivo evaluation of SMEDDS (selfmicroemulsifying drug delivery system) containing fenofibrate. AAPS J. 2007;9:344-352.

43. Pouton CW. Lipid formulations for oral administration of drugs: nonemulsifying, self-emulsifying and self-microemulsifying drug delivery systems. Eur J Pharm Sci. 2000;11:93-108.

44. Pouton CW. Formulation of poorly water-soluble drugs for oral administration: physicochemical and physiological issues and the lipid formulation classification system. Eur J Pharm Sci. 2006;29:278-287.

45. Craig DQM, Baker SA, Banning D, Booth SW. An investigation into the mechanisms of self-emulsification using particle size analysis and low frequency dielectric spectroscopy. Int J Pharm. 1995;11:103-110.

46. Osborne DW, Middleton CA, Rogers RL. Alcohol-free microemulsions. J Dispers Sci Technol. 1988;9:415-423.

47. Pouton CW. Formulation of self-emulsifying drug delivery systems. Adv Drug Deliv Rev. 1997;25:47-58.

48. Zhang $P$, Liu $Y$, Feng $N, X u$ J. Preparation and evaluation of selfemulsifying drug delivery system of oridonin. Int J Pharm. 2008;355:269276.

49. Roland I, Piel G, Delattre L, Evrard B. Systematic characterization of oilin- water emulsions for formulation design. Int J Pharm. 2003;263:85-94.

50. Groves MT, Mustafa RM. Measurement of the spontaneity of self emulsifiable oils. J Pharm Pharmcol. 1974;26:671-681.

51. Pouton CW. Self-emulsifying drug delivery systems: assessment of the efficiency of emulsification. Int J Pharm. 1985;27:335-348. 